\title{
Effect of Xanthan and Arabic Gums on Foaming Properties of Pumpkin (Cucurbita pepo) Seed Protein Isolate
}

\author{
Quirino Dawa ${ }^{1}$, Yufei Hua ${ }^{1}$, Moses Vernonxious Madalitso Chamba ${ }^{1,2}$, Kingsley George Masamba ${ }^{3,4}$ \& \\ Caimeng Zhang ${ }^{1}$ \\ ${ }^{1}$ State Key Laboratory of Food Science and Technology, School of Food Science and Technology, Jiangnan \\ University, 1800 Lihu Road, 214122 Wuxi, Jiangsu Province, China \\ 2 Department of Human Ecology, Domasi College of Education,University of Malawi, P.O. Box 49, Domasi, \\ Zomba, Malawi \\ ${ }^{3}$ Department of Food Science and Technology, Lilongwe University of Agriculture and Natural Resources, \\ Bunda College Campus, P.O Box 219, Lilongwe, Malawi \\ ${ }^{4}$ Laboratory of Hydrocolloids and Biotechnology, School of Food Science and Technology, Jiangnan University, \\ 1800 Lihu Road, 214122 Wuxi, Jiangsu Province, China \\ Correspondence: Yufei Hua, State Key Laboratory of Food Science and Technology, School of Food Science \\ and Technology, Jiangnan University, 1800 Lihu Road, 214122 Wuxi, Jiangsu Province, China. Tel: \\ 86-510-8591-7812. E-mail: yfhua@jiangnan.edu.cn
}

Received: November 24, 2013 Accepted: December 22, 2013 Online Published: December 31, 2013

doi:10.5539/jfr.v3n1p87

URL: http://dx.doi.org/10.5539/jfr.v3n1p87

\begin{abstract}
Understanding how foaming properties of proteins are affected by factors such as $\mathrm{pH}$, salt concentration and temperature is essential in predicting their performance and utilisation. In this study, the effects of $\mathrm{pH}$ and salt concentration were studied on the foaming properties of pumpkin seed protein isolate (PSPI) and PSPI- Xanthan (XG)/Arabic (GA) gum blends. The foaming properties of the PSPI-GA/XG blends were also compared with egg white. Foam stability (FS) was significantly affected by $\mathrm{pH}$ with PSPI: GA (25:4) and PSPI: XG (25:1) having a significantly higher stability at $\mathrm{pH} 2$ with the lowest foam stability at $\mathrm{pH} 4$. Sodium chloride $(0.2-1.0$ M) did not significantly affect foaming properties although PSPI: GA (25:4) had the highest FC (89.33 $\pm 3.24 \%)$ and FS $(76.83 \pm 1.53 \mathrm{~min})$ at $0.2 \mathrm{M}$ sodium chloride concentration. The foaming capacity (FC) of PSPI: GA $(25: 4)$ blend $(128.00 \pm 0.91 \%)$ was significantly higher $(p<0.05)$ than that of egg white $(74.00 \pm 1.33 \%)$ but its FS was significantly lower. It was further revealed that the FC of egg white $(74.00 \pm 1.33 \%)$ was comparable to the PSPI:XG $(25: 1)$ blend $(74.00 \pm 1.46 \%)$ but the FS for egg white $(480.00 \pm 2.67$ min $)$ was significantly higher $(p<0.05)$ than the FS $(116.21 \pm 0.86 \mathrm{~min})$ of PSPI:XG $(25: 1)$. The foaming properties of PSPI and PSPI-xanthan (XG)/Arabic (GA) blends were significantly affected by $\mathrm{pH}$. Optimum foaming properties, PSPI:XG (25:1) and PSPI:GA (25:4) were observed at pH 2 and heat treatment temperature of $80^{\circ} \mathrm{C}$.
\end{abstract}

Keywords: pumpkin seed protein isolate, xanthan gum, Arabic gum, foaming capacity, foam stability

\section{Introduction}

The use of non animal protein sources has progressively increased especially for underprivileged low resource populations in the world primarily due to the high cost of animal protein sources which the majority of the population cannot afford. Research focussing on plant protein for the formulation of new products as well as existing conventional products has been an area of interest in recent years. On an industrial scale, plant proteins are used as ingredients because of specific functional properties that they possess, however, soy bean protein has been the most used plant protein, leaving out other plant proteins that could alternatively be used (Atuonwu \& Akobundu, 2010). Pumpkins (Cucurbita sp) seeds are one of the many other plant protein sources that have shown a potential to be used as an ingredients in food systems as a nutrient and a functional agent (El-Adawy \& Taha, 2001; El-Soukkary, 2001). Pumpkin seeds have been found to contain considerable amounts of proteins. Their products namely isolate, concentrate and flour have demonstrated functional characteristics such as foaming and emulsification that could be of great use in food systems (Atuonwu \& Akobundu, 2010). 
Foaming is an important functional component that is used in many food products such as ice cream and whipped cream. However, stability of foams is a problem and its stabilization is of great significance. Polysaccharides are one of the most widely used stabilizing agents. Some of the polysaccharides that are used include Arabic and xanthan gums, chitosan and pectin (Makri \& Doxastakis, 2006; Kralova \& Sjöblom, 2009). A polysaccharide hydrocolloid will bind water molecules, which leads to enhanced viscosity of aqueous phase both in creams and foams, thereby protecting the whole system against syneresis and ultimately resulting in the eventual stabilization of foams (Sikora, Badrie, Deisingh, \& Kowalski, 2008). Xanthan gum is an exo-cellular polysaccharide derived from Xanthomonas campestris bacteria. At low concentrations, xanthan gum has high viscosity and solubility in water and also highly soluble and stable in acidic conditions (García-Ochoa, Santos, Casas, \& Gómez, 2000). Arabic gum is a heterogeneous polysaccharide composed of a polysaccharide and a protein-polysaccharide complex, obtained from the Acacia senegal tree. It is used as a foam stabilizer but also in food products as an ingredient, mostly in confectionary and beverages because of its low viscosity and high solubility in solution (Walsh, Russell \& FitzGerald, 2008; Makri \& Doxastakis, 2006).

Research relating to plant proteins has been done but the emphasis has been on soy proteins, sunflower, peanuts and cereal crops, legume seeds and oilseeds (Moure, Sineiro, Domínguez \& Parajó, 2006). Studies that have been carried out on pumpkin seed proteins have shown that they have; as do other plant proteins, poor foaming properties (Lasoz, 1992; El-Adawy \& Taha, 2001). The current trend for reduced levels of chemical residues means that research on protein modification will favour the use of non-chemical methods as well as other food components such as proteins, lipids and polysaccharides (Murray, 2007). The use of Arabic, xanthan and other gums to enhance functional properties of plant proteins has been explored with positive results in studies on soy, whey protein and common beans (Makri \& Doxastakis, 2006; Xie \& Hetiarrachchy, 1998; Mott, Hettiarachchy \& Qi, 1999). There is therefore enough scientific evidence that most plant based proteins have poor foaming properties and as such, they need other substances to significantly enhance their foaming properties. This current study was carried out to find out how the incorporation of Arabic and xanthan gums affect the foaming properties of pumpkin seed protein isolate under different $\mathrm{pH}$ ranges and sodium chloride concentrations.

\section{Materials and Methods}

\subsection{Materials}

Pumpkin seed kernels were purchased from Grain Mill Firm in Hohhot City, Inner Mongolia, People's Republic of China. Xanthan gum was purchased from Fufeng Fermentation Co. Ltd in Shandong Province, People's Republic of China, Gum Arabic was purchased from Jiangnan University Chemical store, egg white was purchased from Jiuyuan Homebrew Firm in Shandong, People's Republic of China. All the reagents used in this study were of analytical grade.

\subsection{Methods}

\subsubsection{Preparation of Pumpkin Seed Protein Isolate (PSPI)}

The pumpkin seed kernels were ground into pumpkin seed flour using a portable mill and then passed through a 100 mesh sieve $(150 \mu \mathrm{m})$. The pumpkin seed flour was defatted using the rapid equilibrium method (Clark \& Snyder, 1989) with some modifications. The flour was suspended in $\mathrm{n}$-hexane (bp 30-60 ${ }^{\circ} \mathrm{C}$ ) in a glass bottle using flour to solvent ratio of 1:4 (w/v). The flour-hexane slurry was shaken for 10 minutes-this procedure was repeated twice to remove residual lipids. After shaking, the miscella was filtered and the liquid was distilled to retain the hexane. The defatted flour was dried under a fume hood and then passed through a 100 mesh sieve $(150 \mu \mathrm{m})$. Pumpkin seed protein isolate (PSPI) was prepared according to Nkosi, Opoku and Terblanche (2005). The defatted flour was weighed and mixed with distilled water in the ratio of $1: 10(\mathrm{w} / \mathrm{v})$. The $\mathrm{pH}$ of the suspension was adjusted to 10 with $5 \mathrm{M} \mathrm{NaOH}$ and $\mathrm{HCl}$, stirred for $1 \mathrm{~h}$ at ambient temperature, then centrifuged at $10000 \mathrm{xg}, 4^{\circ} \mathrm{C}$ for $30 \mathrm{~min}$. The supernatant was adjusted to $\mathrm{pH} 5$ with $2 \mathrm{M} \mathrm{HCl}$, stirred for $30 \mathrm{~min}$, settled for $1 \mathrm{~h}$ and and then centrifuged again at $10000 \mathrm{xg}, 4^{\circ} \mathrm{C}$ for $30 \mathrm{~min}$. The precipitate was re-suspended in distilled water in an adjusted $\mathrm{pH}$ of 7.0 using $1 \mathrm{M} \mathrm{NaOH}$ and $\mathrm{HCl}$, homogenized and agitated. The re-solubilised protein was then spray dried using a 0.8 GEA Niro fluidised spray dryer (GEA Process Engineering A/S Gladsaxevej Søborg - Denmark). The feed flow was $0.6 \mathrm{l} / \mathrm{h}$ with an inlet and outlet temperature of $150{ }^{\circ} \mathrm{C}$ and $60{ }^{\circ} \mathrm{C}$ respectively. The protein content of the PSPI was $87.64 \%$ as determined by the micro-Kjeldhal method using nitrogen to protein conversion factor of 6.25 (American Association of Cereal Chemists [AACC], 2000).

\subsubsection{Effect of Xanthan and Arabic Gums on PSPI Foaming Capacity and Stability}

Pumpkin seed protein isolate-xanthan /Arabic gum (PSPI-XG and GA) dispersions were made by dry-mixing separate $0.5 \mathrm{~g}$ portions of PSPI with $0.02,0.04,0.06,0.08,0.1 \mathrm{~g}$ of $\mathrm{XG}$ and GA, giving PSPI:XG/GA ratios of 
25:1, 25:2, 25:3, 25:4 and 5:1 respectively. Five PSPI-XG and GA dispersions were prepared (by transferring the blends into $50 \mathrm{ml}$ of $0.1 \mathrm{M}$ sodium phosphate buffer $(\mathrm{pH} \mathrm{7.0)}$ ) while stirring with a magnetic stirrer for 60 min at ambient temperature. Foams were then made using a rod homogenizer (IKA T18 basic Model T18B525 Ultra-Turrax homogenizer) for $2 \mathrm{~min}$ and then transferred into a $250 \mathrm{ml}$ measuring cylinder. Foam capacity was determined immediately after transferring into the foam into the measuring cylinder, while foam stability was determined by monitoring the decrease in foam volume over time $(\Delta \mathrm{t} 30 \mathrm{~min})$. Egg white was used as a standard. Foaming capacity (FC) and foam stability (FS) were calculated using the equations below:

$$
\mathrm{FC}=\mathrm{FV} / \mathrm{V} \times 100 \%
$$

Where:

$\mathrm{FC}=$ foaming capacity

$\mathrm{FV}=$ foam volume

$\mathrm{V}=$ initial sample volume

$$
\mathrm{FS}=\mathrm{V}_{0} \times \Delta \mathrm{t} / \Delta \mathrm{V}
$$

Where:

Where: FS = foaming stability,

$\mathrm{V}_{0}=$ initial foam volume,

$\Delta \mathrm{t}=30 \mathrm{~min}$,

$\Delta \mathrm{V}=$ change in foam volume after $30 \mathrm{~min}$.

From the preliminary foaming results, PSPI:XG (25:1) and PSPI:GA (25:4) blends were selected to study their response to salt, $\mathrm{pH}$ and heat treatments.

\subsubsection{Salt Treatment}

PSPI, PSPI:XG (25:1) and PSPI:GA (25:4) were each solubilised in $50 \mathrm{ml}$ solutions of $2 \mathrm{M}, 4 \mathrm{M}, 6 \mathrm{M}, 8 \mathrm{M}$ and $10 \mathrm{M} \mathrm{NaCl}$ (adjusted to $\mathrm{pH} 7.0$ with $0.1 \mathrm{M} \mathrm{NaOH}$ and $\mathrm{HCl}$ ). These dispersions were used to determine foaming properties.

\subsubsection{PH Treatment}

PSPI, PSPI:XG (25:1) and PSPI:GA (25:4) were each solubilised in $50 \mathrm{ml}$ of distilled water which was adjusted to a $\mathrm{pH}$ of $2.0,4.0,6.0,8.0$ and 10 , with $0.1 \mathrm{M} \mathrm{NaOH}$ or $\mathrm{HCl}$. These solutions were used to study foaming properties.

\subsubsection{Heat Treatment}

PSPI, PSPI:XG (25:1) and PSPI:GA (25:4) were each solubilised in $50 \mathrm{ml}$ of $0.1 \mathrm{M}$ sodium phosphate buffer (pH 7.0). The solutions were then heated at $80{ }^{\circ} \mathrm{C}$ for 10,20 and $30 \mathrm{~min}$, cooled to ambient temperature, and evaluated for foaming properties. Preliminary work on the different temperatures used in the study identified 80 ${ }^{\circ} \mathrm{C}$ as providing better foaming properties and the choice of this temperature was also supported by findings of Cheftel, Cuq and Lorient (1985) who reported improvement of foaming properties of soy bean by moderate heating at temperatures in the range of $70-80{ }^{\circ} \mathrm{C}$.

\subsubsection{Statistical Analysis}

Data from the study was analysed using SPSS version 16.0 and means were compared for significant difference using ANOVA and Duncan's multiple range test at 5\% significant level.

\section{Results}

\subsection{Effect of Xanthan and Arabic Gums on PSPI Foaming Capacity and Stability}

Results on the effect of xanthan and Arabic gums at different ratios with PSPI are presented in Tables 1. The results show that PSPI:XG (25:1) and PSPI:GA (25:4) blends have better foaming capacity and foam stability compared to the other blends. Xanthan gum did not display any foaming properties, GA foaming properties were not significantly different $(p<0.05)$ from PSPI. 
Table 1. Foaming capacity and stability properties of PSPI-XG and PSPI-GA blends

\begin{tabular}{lllll}
\hline Treatment & \multicolumn{2}{c}{ Foaming capacity (\%) } & \multicolumn{2}{c}{ Foam stability (min) } \\
& PSPI-XG & PSPI-GA & PSPI-XG & PSPI-GA \\
\hline PSPI:XG/GA (25:1) & $74.00 \pm 1.46^{\mathrm{a}}$ & $132.67 \pm 1.58^{\mathrm{ab}}$ & $116.21 \pm 0.86^{\mathrm{a}}$ & $120.50 \pm 1.69^{\text {cd }}$ \\
PSPI:XG/GA (25:2) & $60.00 \pm 0.90^{\mathrm{a}}$ & $137.33 \pm 1.02^{\mathrm{a}}$ & $73.74 \pm 0.58^{\mathrm{a}}$ & $116.36 \pm 0.97^{\text {cd }}$ \\
PSPI:XG/GA (25:3) & $61.33 \pm 1.11^{\mathrm{a}}$ & $117.33 \pm 2.42^{\mathrm{b}}$ & $59.88 \pm 0.87^{\mathrm{a}}$ & $115.39 \pm 1.25^{\mathrm{cd}}$ \\
PSPI:XG/GA (25:4) & $35.33 \pm 1.23^{\mathrm{b}}$ & $128.00 \pm 0.91^{\mathrm{ab}}$ & $74.05 \pm 1.38^{\mathrm{a}}$ & $233.48 \pm 1.35^{\mathrm{b}}$ \\
PSPI:XG/GA (5:1) & $40.00 \pm 0.93^{\mathrm{b}}$ & $120.00 \pm 1.00^{\mathrm{b}}$ & $63.81 \pm 1.19^{\mathrm{a}}$ & $193.93 \pm 1.05^{\mathrm{bc}}$ \\
PSPI & $42.67 \pm 1.62^{\mathrm{b}}$ & & $43.62 \pm 0.95^{\mathrm{a}}$ & \\
Eggwhite & $74.00 \pm 1.33^{\mathrm{a}}$ & & $480.00 \pm 2.67^{\mathrm{b}}$ & \\
XG & $0.00 \pm 0.00^{\mathrm{c}}$ & & $0.00 \pm 0.00^{\mathrm{e}}$ & \\
GA & $28.27 \pm 1.20^{\mathrm{b}}$ & & $21.00 \pm 1.22^{\mathrm{a}}$ & \\
\hline
\end{tabular}

Means in the same column with different superscripts are significantly different at $p<0.05$.

Although FS $(480.00 \pm 2.67 \mathrm{~min})$ of eggwhite was significantly higher than PSPI and the PSPI-XG blends, its FC $(74.00 \pm 1.33 \%)$ was not significantly different from PSPI: XG (25:1) at the value of $74.00 \pm 1.46 \%$, PSPI: XG (25:2) at the value of $60.00 \pm 0.90 \%$ and PSPI: XG (25:3) at the value of $61.33 \pm 1.11$ (Table 1).

Relatively higher FC and FS values were observed with the PSPI-GA blends. The FC value (128.00 $\pm 0.91 \%)$ of PSPI:GA (25:4) was significantly higher than that of egg white (74.00 $\pm 1.33 \%)$.

\subsection{Salt Treatment Effect on Foaming Capacity and Stability}

The FC values of PSPI: XG (25:1) were lower than PSPI and PSPI: GA (25:4). Although PSPI:GA (25:4) produced higher FC and FS values, they were not significantly different from the FC and FS values of PSPI alone (Table 2) and the FC and FS values for each respective sample (PSPI, PSPI:XG (25:1) and PSPI:GA (25:4) at the different concentrations $(0.2-1.0 \mathrm{M})$ were not significantly different $(p<0.05)$ from one another.

Table 2. Effect of salt concentration on foaming capacity and stability

\begin{tabular}{lll}
\hline Treatment & Foaming capacity (\%) & Foam stability (min) \\
\hline PSPI & & \\
$0.2 \mathrm{M} \mathrm{NaCl}$ & $74.67 \pm 4.05^{\mathrm{ab}}$ & $38.80 \pm 3.10^{\mathrm{a}}$ \\
$0.4 \mathrm{M} \mathrm{NaCl}$ & $78.67 \pm 2.31^{\mathrm{ab}}$ & $88.55 \pm 3.74^{\mathrm{a}}$ \\
$0.6 \mathrm{M} \mathrm{NaCl}$ & $78.67 \pm 2.31^{\mathrm{ab}}$ & $79.52 \pm 1.23^{\mathrm{a}}$ \\
$0.8 \mathrm{M} \mathrm{NaCl}$ & $70.67 \pm 2.22^{\mathrm{ab}}$ & $68.59 \pm 1.33^{\mathrm{a}}$ \\
$1.0 \mathrm{M} \mathrm{NaCl}$ & $61.33 \pm 2.31^{\mathrm{cb}}$ & $97.50 \pm 1.39^{\mathrm{a}}$ \\
PSPI:XG (25:1) & \\
$0.2 \mathrm{M} \mathrm{NaCl}$ & $48.67 \pm 4.62^{\mathrm{c}}$ & $52.34 \pm 2.24^{\mathrm{a}}$ \\
$0.4 \mathrm{M} \mathrm{NaCl}$ & $52.00 \pm 2.00^{\mathrm{cb}}$ & $56.25 \pm 1.83^{\mathrm{a}}$ \\
$0.6 \mathrm{M} \mathrm{NaCl}$ & $48.67 \pm 4.16^{\mathrm{c}}$ & $75.83 \pm 2.26^{\mathrm{a}}$ \\
$0.8 \mathrm{M} \mathrm{NaCl}$ & $43.33 \pm 4.16^{\mathrm{c}}$ & $59.09 \pm 2.67^{\mathrm{a}}$ \\
$1.0 \mathrm{M} \mathrm{NaCl}$ & $48.67 \pm 4.16^{\mathrm{c}}$ & $47.92 \pm 1.91^{\mathrm{a}}$ \\
PSPI: GA (25:4) & & \\
$0.2 \mathrm{M} \mathrm{NaCl}$ & $89.33 \pm 3.24^{\mathrm{a}}$ & $76.83 \pm 1.53^{\mathrm{a}}$ \\
$0.4 \mathrm{M} \mathrm{NaCl}$ & $80.67 \pm 1.01^{\mathrm{ab}}$ & $62.77 \pm 0.94^{\mathrm{a}}$ \\
$0.6 \mathrm{M} \mathrm{NaCl}$ & $80.67 \pm 1.47^{\mathrm{ab}}$ & $66.91 \pm 0.10^{\mathrm{a}}$ \\
$0.8 \mathrm{M} \mathrm{NaCl}$ & $88.67 \pm 1.43^{\mathrm{a}}$ & $50.85 \pm 3.24^{\mathrm{a}}$ \\
$1.0 \mathrm{M} \mathrm{NaCl}$ & $70.67 \pm 9.23^{\mathrm{ab}}$ & $59.61 \pm 10.58^{\mathrm{a}}$ \\
\hline
\end{tabular}

Means in the same column with different superscripts are significantly different at $p<0.05$. 


\subsection{Foaming Properties as Influenced by $\mathrm{pH}$}

The results on the effects of $\mathrm{pH}$ on FC and FS of different PSPI-gum blends are presented in Figures 1 and 2. The FC for the three samples (PSPI-69.33\%; PSPI:XG (25:1)-75.33\%; PSPI:GA (25:4) - 63.34\%) was highest at $\mathrm{pH} 2$ (Figure 1), but no significant difference $(p<0.05)$ was observed among them. At the same pH level $(\mathrm{pH} 2)$, the similar increased trend was observed in FS (Figure 2). However, PSPI showed significantly lower FS than the other two samples, which did not differ.

The FS values (PSPI 376.67 min; PSPI: XG (25:1) 565 min; PSPI: GA (25:4) 615 min) (Figure 2) at pH 2 were also high, PSPI: XG (25:1) and PSPI: GA (25:4) values were not significantly different from each other $(p<$ $0.05)$, but were both significantly higher than PSPI $(p<0.05)$. Minimum foaming properties were observed at $\mathrm{pH} 4$ for all the samples (Figure 1 and 2). From $\mathrm{pH} 6$ to $\mathrm{pH}$ 8, FC for PSPI and PSPI: XG (25:1) in Figure 1 increased and this increase was also observed for PSPI:GA (25:4) from $\mathrm{pH} 4-6$, with a decrease at $\mathrm{pH} 8$.

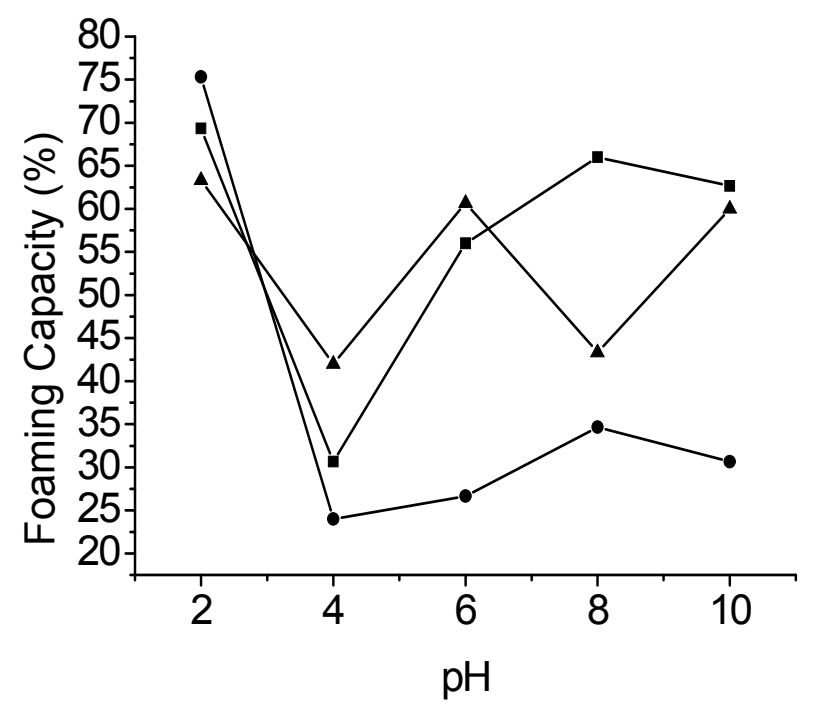

Figure 1. Effect of $\mathrm{pH}$ on foaming capacity of PSPI SPI:XG (25:1) and PSPI:GA (25:4)

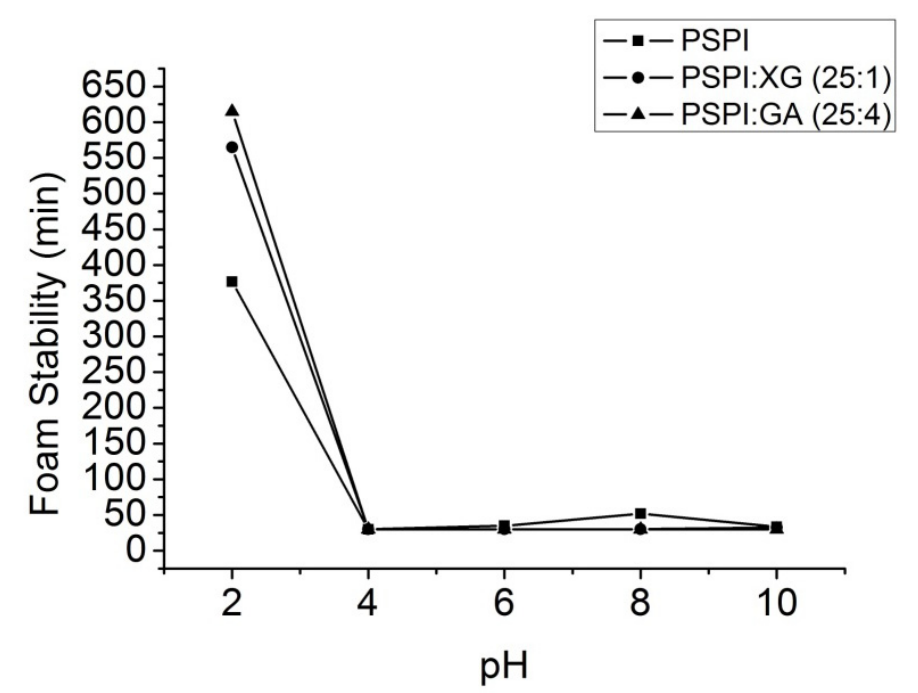

Figure 2. Effect of $\mathrm{pH}$ on foam stability of PSPI, SPI:XG (25:1) and PSPI:GA (25:4) 


\subsection{Effect of Heating Time on Foaming Properties}

Figure 3 and 4 show effects of various time-bound heat treatments on the foaming properties of the samples. No significant differences $(p<0.05)$ in foaming properties were noted amongst the samples, although PSPI produced high $\mathrm{FC}$ and $\mathrm{FS}$ values after heating for $30 \mathrm{~min}$.

The results in Figure 4 have shown that heating improved FS, with values ranging from 190-380 min. PSPI: GA (25:4) and PSPI: XG (25:1) had higher FS values after 10 and 20 min of heating respectively.

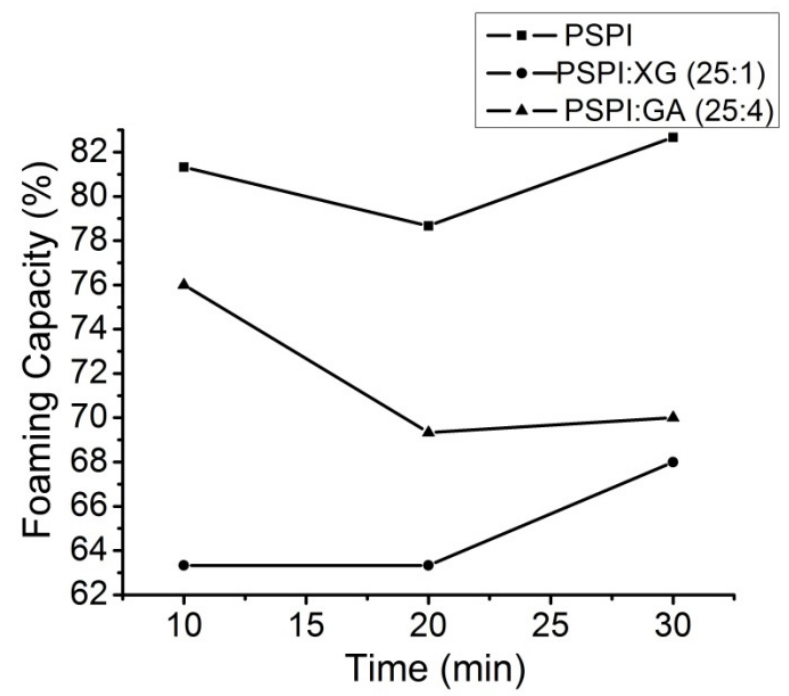

Figure 3. Effect of heating time on foaming capacity of PSPI, SPI:XG (25:1) and PSPI:GA (25:4)

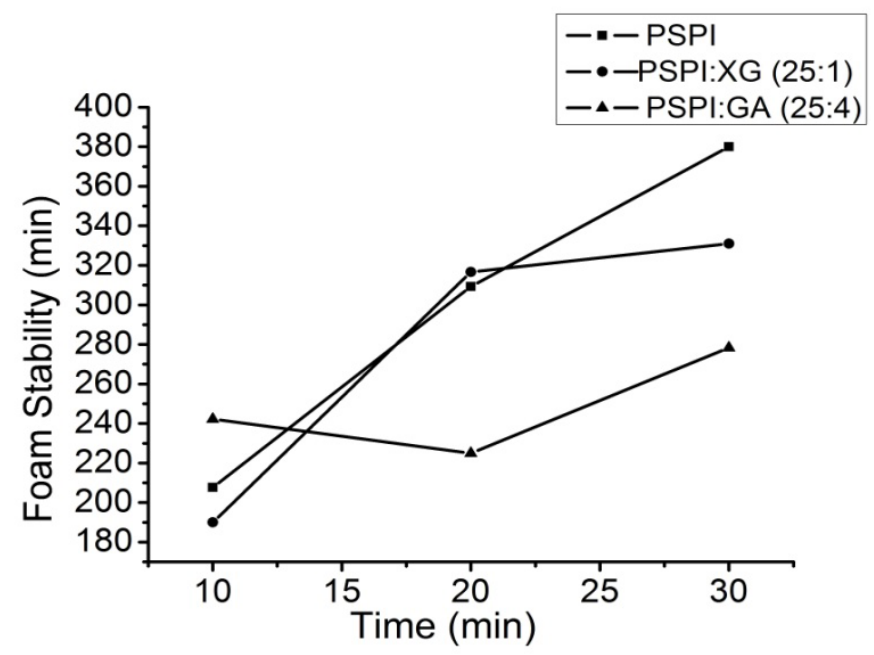

Figure 4. Effect of heating time on foam stability of PSPI, SPI:XG (25:1) and PSPI:GA (25:4)

\section{Discussion}

\subsection{Effect of Xanthan Gum and Arabic Gum on PSPI Foaming Capacity and Stability}

Results have shown that the addition of the gums (xanthan and Arabic) to PSPI improved the FC and FS. The presence of these gums generally increases the liquid viscosity, forms cohesive flexible films around the air bubbles and reduces the interaction forces in the solution resulting in improved foaming properties (Symes, 1980; 
Sanderson, 1981). The high foaming property values of the PSPI-GA blends relative to the PSPI-XG blends can be attributed to the protein components (approximately 1\%) that are present in the gum (Mahendran, Williams, Phillips, \& Al-Assaf, 2008; Karamallah, 2000) and this also explains why GA displayed foaming properties as opposed to XG. With a higher protein concentration the rate of protein diffusion to the air-water interface is also high and increases the foaming capacity (Rodríguez Patino et al., 2007).

\subsection{Effect of Salt Concentration on Foaming Capacity and Stability}

The findings of this study are in contrast to findings from studies carried out on whey protein isolate and soy protein isolate by Mott et al. (1999) and Xie and Hettiarachchy (1998) respectively in which sodium chloride was reported to have a positive effect on the protein-gum interaction at $\mathrm{pH}$ 7.4. The findings in this study are however, supported by Lindman et al. (2006), who reported that protein stability was not affected by different sodium chloride concentration levels at $\mathrm{pH} 7.5$ because the total net charge of proteins at $\mathrm{pH} 7.5$ is high, resulting in high interaction of the charges and because of these close interactions, there are high repulsive forces which affect protein unfolding resulting in poor protein stability. Due to the poly electrolyte nature of xanthan and Arabic gums (Makri \& Doxastakis, 2006; Garcia-Ochoa, Santos, Casas, \& Gómez, 2000), the flexible film networks formed by the PSPI- XG/GA interactions around the bubbles in the solution could have been negatively affected by the addition of sodium chloride and may have contributed further to the repulsive forces resulting in reduced foaming properties. At lower $\mathrm{pH}$ conditions increase in $\mathrm{NaCl}$ concentration causes an increase in protein stability (Lindman et al., 2006), which results in unfolding, viscosity, solubility and aggregation of proteins, which in turn affect foaming properties by increasing the solvent surface tension,decreasing the solubility of nonpolar molecules and ultimately strengthening hydrophobic interactions (Cheftel et al., 1985; Mao, Sheng, \& Pan, 2007). Therefore salt treatment conditions under much lower pH conditions could most likey improve the foaming properties.

\subsection{Effect of pH on Foaming Properties}

The maximum foaming properties for all the samples was observed at $\mathrm{pH} 2$. Kinsella (1976) similarly reported that unfolding of undenatured protein has been observed to occur under acidic values, below but close to the isoelectric point. The maximum foaming properties are a result of protein unfolding, although Mott et al. (1999) reported that protein unfolding can reduce film thickness, ultimately reducing stability. The reduced foaming properties that were observed at $\mathrm{pH} 4$ are a result of decreased solubility and strong intermolecular forces that do not allow unfolding and spreading leading to low foaming properties (Nath \& Narasinga Rao, 1981). The increase in FC between $\mathrm{pH} 6$ and $\mathrm{pH} 8$ can be attributed to protein unfolding which takes place in alkaline conditions, foams made under these $\mathrm{pH}$ (4-10) conditions were however, not stable, films formed in alkaline conditions by XG and GA were affected and this may have reduced the stability of these foams.

\section{Conclusion}

The results from this study have demonstrated that both xanthan and Arabic gums can significantly enhance the foaming properties of Pumpkin seed protein isolate. The results have further revealed that $\mathrm{pH}$ significantly affects the effectiveness of foaming properties enhancing substances such as xanthan and Arabic gums while different salt concentrations levels did not affect the foaming properties of pumpkin seed protein isolate, but application of the salt concentration levels under lower $\mathrm{pH}$ conditions would most likely improve the results. From the results of this study, it can be concluded that in order to achieve optimum improved foaming properties of pumpkin seed protein isolate, PSPI:XG and PSPI: GA blends in the ratios of 25:1 and 25:4 respectively give high foaming properties at $\mathrm{pH} 2$ and heat treatment of $80^{\circ} \mathrm{C}$ for $30 \mathrm{~min}$. Due to the limiting $\mathrm{pH}$ factor, there is a need for further studies on the application of these foam in a real food systems, such as creams and maringues especially under much higher $\mathrm{pH}$ ranges (6-7), in which foam stability is a problem.

\section{Acknowledgement}

The authors gratefully acknowledge the financial support from State Key Laboratory of Food Science and Technology and the support offered by staff and students from the Vegetable Protein Laboratory of the School of Food Science and Technology, Jiangnan University, China.

\section{Reference}

American Association of Cereal Chemists. (2000). Crude protein-Micro kjeldhal method. In Approved methods of the AACC 2. AACC method (10th ed., pp. 46-13). St. Paul, MN, USA.

Atuonwu, A. C., \& Akobundu, E. N. T. (2010). Functional and pasting properties of pumpkin (Cucurbita pepo) seed products. Journal of Agriculture and Veterinary Sciences, 2, 36-49. 
Cheftel, J. C., Cuq, J. L., \& Lorient, D. (1985). Amino acids, peptides, and proteins. In O. W. Fennema (Ed.). Food Chemistry (pp. 245-370). Marcel Dekker, New York.

Clark, P. K., \& Snyder, H. E. (1989). Factors affecting the rapid equilibrium method for analysis of total oil in soybean cultivars. Journal of the American Oil Chemists' Society, 66(9), 1316-1320. http://dx.doi.org/10.1007/BF03022753

El-Adawy, T. A., \& Taha, K. M. (2001). Characteristics and composition of watermelon, pumpkin and paprika seed oils and flours. Journal of Agriculture and Food Chemistry, 49, 1253-1259. $\mathrm{http}: / / \mathrm{dx}$. doi.org/10.1021/jf001117+

El-Soukkary, A. H. (2001). Evaluation of pumpkin seed products for bread fortification. Plant Food and Human Nutrition, 56, 365-384. http://dx.doi.org/10.1023/A:1011802014770

García-Ochoa, F., Santos, V. E., Casas, J. A., \& Gómez, E. (2000). Xanthan gum: production, recovery and properties. Biotechnology Advances, 18, 549-579. http://dx.doi.org/10.1016/S0734-9750(00)00050-1

Kinsella, J. E. (1976). Functional properties of proteins in foods: a survey. Critical Reviews in Food Science and Nutrition, 7, 219-232. http://dx.doi.org/10.1080/10408397609527208

Kralova, I., \& Sjöblom, J. (2009). Surfactants used in food industry: a review. Journal of Dispersion Science and Technology, 30(9), 1363-1383. http://dx.doi.org/10.1080/01932690902735561

Karamallah, K. A. (2000). Gum Arabic-quality and quantity assured. In P. A. Williams \& G. O. Phillips (Eds.), Gums and stabilizers for the food industry, Vol. 10 (pp. 37-52). UK: The Royal Society of Chemistry.

Lazos, E. S. (1992). Certain functional properties of defatted pumpkin seed flour. Plant Foods for Human Nutrition, 42, 257-273. http://dx.doi.org/10.1007/BF02193934

Lindman, S., Xue, W. F., Szczepankiewicz, O., Bauer, M. C., Nilsson, H., \& Linse, S. (2006). Salting the Charged Surface: pH and Salt Dependence of Protein G B1 Stability. Biophysical Journal, 90(8), 2911-2921. http://dx.doi.org/10.1529/biophysj.105.071050

Makri, E. A., \& Doxastakis, G. I. (2006). Study of emulsions stabilized with Phaseolus vulgaris or Phaseolus coccineus with the addition of Arabic gum, locust bean gum and xanthan gum. Food Hydrocolloid, 20, 1141-1152. http://dx.doi.org/10.1016/j.foodhyd.2005.12.008

Mao, Y. J., Sheng, X. R., \& Pan, X. M. (2007). The effects of $\mathrm{NaCl}$ concentration and $\mathrm{pH}$ on the stability of hyperthermophilic protein Ssh10b. BMC Biochemistry, 8, 1-8. http://dx.doi.org/10.1186/1471-2091-8-1

Mott, C. L., Hettiarachchy, N. S., \& Qi, M. (1999). Effect of xanthan gum on enhancing the foaming properties of whey protein isolate. Journal of American Oil Chemists' Society, 76, 1383-1386. http://dx.doi.org/10.1007/s11746-999-0154-8

Moure, A., Sineiro, J., Domínguez, H., \& Parajó, J. C. (2006). Functionality of oilseed protein products: A review. Food Research International, 39, 945-963. http://dx.doi.org/10.1016/j.foodres.2006.07.002

Murray, B. S. (2007). Stabilization of bubbles and foams. Current Opinion in the Colloid and Interface Science, 12, 232-241. http://dx.doi.org/10.1016/j.cocis.2007.07.009

Mahendran, T., Williams, P. A., Phillips, G. O., Al-Assaf, S., \& Baldwin, T. C. (2008). New insights into the structural characteristics of the arabinogalactan-protein (AGP) fraction of gum Arabic. Journal of Agricultural and Food Chemistry, 56, 9296-9297. http://dx.doi.org/10.1021/jf800849a

Nath, J. P., \& Narasinga Rao, M. S. (1981). Functional properties of Guar proteins. Journal of Food Science, 46, 1255-1259. http://dx.doi.org/10.1111/j.1365-2621.1981.tb03034.x

Nkosi, C. Z., Opoku, A. R., \& Terblanche, S. E. (2005). Effect of pumpkin seed (Cucurbita pepo) protein isolate on the activity levels of certain plasma enzymes in $\mathrm{CCl}_{4}$-induced liver injury in low-protein fed rats. Phytotherapy Research, 19, 341-345. http://dx.doi.org/10.1002/ptr.1685

Rodríguez, P. J. M., Minõnes, C. J., Millán, L. H., Pedroche, J. J. J., Carrera, S. C., Pizones, V., \& Millán, R. F. (2007). Interfacial and foaming properties of enzyme-induced hydrolysis of sunflower protein isolate. Food Hydrocolloids, 21, 782-793. http://dx.doi.org/10.1016/j.foodhyd.2006.09.002

Sanderson, G. R. (1981). Polysaccharides in foods. Food Technology, 35, 50-83.

Sikora, M., Badrie, N., Deisingh, N. K., \& Kowalski, S. (2008). Sauces and dressings: a review of properties and applications. Critical Reviews in Food Science and Nutrition, 48, 50-77. http://dx.doi.org/10.1080/10408390601079934 
Symes, K. C. (1980). The Relationship between the Covalent Structure of the Xanthomonas polysaccharide (Xanthan) and its function as a thickening, suspending and gelling agent. Food Chemistry, 6, 63-76. http://dx.doi.org/10.1016/0308-8146(80)90007-2

Walsh, D. J., Russell, K., \& FitzGerald, R. J. (2008). Stabilisation of sodium caseinate hydrolysate foams. Food Research International, 41, 43-52. http://dx.doi.org/10.1016/j.foodres.2007.09.003

Wani, A. A., Sogi, D. S., Singh, P., Wani, I. A., \& Shivhare, U. S. (2011). Characterisation and functional properties of watermellon (Citrullus lanatus) seed proteins. Journal of the Science of Food and Agriculture, 91, 113-121. http://dx.doi.org/10.1002/jsfa.4160

Xie, Y. R., \& Hettiarachchy, N. R. (1998). Effect of Xanthan gum on enhancing the foaming properties of soy protein isolate. Journal of American Oil Chemists' Society, 75, 729-732. http://dx.doi.org/10.1007/s11746-998-0214-5

\section{Copyrights}

Copyright for this article is retained by the author(s), with first publication rights granted to the journal.

This is an open-access article distributed under the terms and conditions of the Creative Commons Attribution license (http://creativecommons.org/licenses/by/3.0/). 